\title{
Top 100 Most Influential Articles in the Field of Myeloid Neoplasms: A Bibliometric Study
}

\author{
Unzela lqbal $^{\mathrm{a}}$ Aiman Rehan $^{\mathrm{a}}$ Manahil Akmal $^{\mathrm{a}}$ Momal Jamalia $^{\mathrm{a}}$ Abiha lqbal $^{\mathrm{b}}$ \\ Bilal Ahmed Khan ${ }^{a}$ Khawaja Uzair Wasifa Erika Rivera ${ }^{c}$ Maliha Khan ${ }^{d}$ \\ a Dow Medical College, Dow University of Health Sciences, Karachi, Pakistan; b Dow International Medical College, \\ Dow University of Health Sciences, Karachi, Pakistan; ' Johns Hopkins School of Medicine, Johns Hopkins University, \\ Baltimore, MD, USA; d Department of Leukemia, The University of Texas MD Anderson Cancer Center, Houston, \\ TX, USA
}

\section{Keywords}

Bibliometrics · Citation classics · Acute myelogenous

leukemia $\cdot$ Leukemia $\cdot$ Neoplasms

\begin{abstract}
Background: Bibliometric analyses are a tool employed by researchers and funding agencies to establish the most important areas of research in a particular field, and to determine which foci need increased research attention. Such analyses have been published in a variety of clinical specialties; however, a detailed literature search showed that no such study has been done for "myeloid neoplasms." In order to bridge this gap, we conducted a citation analysis of the 100 most influential articles on myeloid neoplasms. Methods: Two independent researchers extracted relevant articles from the Scopus database. These articles were then ranked in descending order of citations and a list of the top 100 original articles was made. A further, more detailed list was created containing significant discriminating characteristics. Results: The top cited articles were published over a period of 47 years, with most of them being published in the 5-year interval of 2001-2005. The citations ranged from 636 to 4,039 . The articles originated from 28 different countries.
\end{abstract}

\section{KARGER}

(c) 2019 S. Karger AG, Basel

E-Mail karger@karger.com

www.karger.com/aha
Most of the articles were published in high-impact journals. Conclusion: Our analysis sheds light on the quality of work and driving trends, listing the most cited and impactful guideline articles within this field and aiding clinicians.

(c) 2019 S. Karger AG, Basel

\section{Introduction}

As medicine advances, there is also an ever increasing emergence of medical and scientific knowledge. This presents an urgent need to identify the most significant research findings that will lay future clinical and theoretical foundations. Therefore, there is a growing interest in the evaluation of research so as to establish the most impactful papers within a field, their authors, and their countries of origin [1]. Bibliometric analysis is a powerful tool that allows us to do this [2]. This method is based on quantitative measures and, although its efficacy in quantifying the abstract concept of "quality" is often debated [3], its use by scientists and institutions has been gradually increasing over the last few years [4]. It has implications not only for individual researchers but also for the agencies financing those researchers and for government 
policymakers to reorient the allocation of funds and resources [5].

Myeloid neoplasms comprise a group of hematologic malignancies that originate from a myeloid cell lineage [6]. Our understanding of the biology of myeloid neoplasms has undergone substantial changes over the last 2 centuries. Their complex pathogenesis, profound genetic heterogeneity, diagnostic dilemma, and extreme variability in response to treatment continue to challenge researchers even today [7]. The classification of these neoplasms alone has been a momentous task requiring the consensus of over a hundred pathologists, hematologists, oncologists, and geneticists [8]. The World Health Organization (WHO) releases updated and revised classification schemes for myeloid malignancies every few years as new research unravels further information about their biology. There have been quite a number of bibliometric studies done on various specialties and subspecialties [916]. However, no bibliometric analysis has been performed for myeloid neoplasms. Realizing this deficiency and in an effort to bridge this gap, we performed a bibliometric analysis to identify the characteristics of the top cited articles in this field.

\section{Methods}

In September 2017, the Scopus database was searched independently by 2 reviewers (A.R. and U.I.) for citations of published articles on "myeloid neoplasms." Keywords were extracted from a number of sources including Google, the MeSH database, the International Classification of Disease-10 (ICD-10), and the 2008 WHO classification scheme for myeloid neoplasms. In order to include a large variety of articles, no exclusion criteria were set for human versus nonhuman subjects, abstract availability, or study design. Furthermore, no restriction of time limit was imposed, and all of the journals available on the database were included. The first search comprised both original and review articles and was then modified by placing a filter available on Scopus to only include the original articles.

Our keywords consisted of "Myeloproliferative disorder," "Polycythemia Vera," "Acute Myeloid Leukemia," "Chronic Myelogenous Leukemia," "Myelofibrosis", "Essential Thrombocythemia," "Chronic Myelomonocytic Leukemia," "Juvenile Myelomonocytic Leukemia," "Atypical Chronic Myeloid Leukemia," "Systemic Mastocytosis," "Systemic Mast Cell Disease," "Chronic Myeloid Leukemia," "Acute Erythroblastic Leukemia," "Chronic Neutrophilic Leukemia," "Chronic Eosinophilic Leukemia," "Polycythemia Rubra Vera," "Myeloproliferative Neoplasms," "Hereditary Erythrocytosis," "Hereditary Thrombocytosis," "Familial Myeloproliferative Neoplasms," "Myelodysplastic Syndromes," "Hypereosinophilic Syndrome," "Mast Cell Disease," "MPN," "MDS," "AML," and "CML." Each keyword was searched for in article titles, abstracts, and keywords. Articles concerning the epidemiology, diagnosis, treatment, prognosis, and molecular genetics of myeloid neoplasms were all included in the list. Scopus results were sorted by the "Cited by" filter and a list of articles was extracted. Abstracts of all the articles on the list were reviewed in order to gauge their relevance and a final list of the top 100 articles was prepared independently by the 2 reviewers, an approach introduced by Lim et al. [9]. For any article to be included in the final list, a mutual consensus between 2 reviewers was required. An analysis of citations was obtained both by Scopus and manual screening and the following information was retrieved for each article: citation count, country of origin, journal name with impact factor, year of publication, and number of authors along with their $\mathrm{H}$ index. For articles with authors from multiple countries, the first author's country was regarded as the country of origin. Impact factor for journals were obtained from Thomson Reuters Journal Citation Report. Means, medians, and interquartile ranges (IQR) were calculated for both the total number of citations and the number of citations per year. Tables and charts were created using $\mathrm{Mi}$ crosoft Word and Microsoft Excel, respectively. In order to determine the correlation between the journal impact factor and the number of papers published in that journal, a Pearson product moment correlation test was applied using IBM SPSS Statistics 23.0. $p<0.05$ was considered statistically significant. No ethical approval was sought for this study since it did not involve human subjects or data and was merely an evaluation of previously published data.

\section{Results}

Table 1 lists the top 100 most cited articles in the field of myeloid neoplasms, along with their total citations and citations per year. The citations of these top 100 articles ranged from 636 to 4,039 , with a median of 972.5 citations per article (IQR 578.25). The sum of all of the citations was 125,691 , among which $8 \%$ were self-citations. Citations per year ranged from 15.9 to 292.5 . The mean and median number of citations per year was 91.3 and 80.8 , respectively (IQR 80.5).

Figure 1 represents the total citations of the articles each year. A steady number of citations was observed until 1980, after which a gradual increase was seen up to 2000. The number of citations increased rapidly thereafter, peaking in 2015 with the most number of citations $(n=8,120)$, followed by a steep decline. Figure 2 shows the distribution of the number of publications of the top 100 articles by 5 -year intervals. The 100 most cited articles were published over a span of 47 years from 1966 to 2013 , with the highest number of articles published in the 5 -year period from 2001 to 2005.

The top 100 articles originated from 28 different countries. The highest number of articles $(n=69)$ originated from the USA, followed by Germany $(n=24)$, the UK $(n=24)$, and France $(n=17)$. Four publications on the list had an unidentified country of origin (Fig. 3). A total 
Table 1. Top 100 articles, their citations, and citations per year

Rank Article

Total citations,

Bonnet D, Dick JE: Human acute myeloid leukemia is organized as a hierarchy that originates from a primitive hematopoietic cell. Nat Med 1997;3:730-737.

2 Bennett JM, Catovsky D, Daniel MT, et al: Proposals for the classification of the acute leukaemias. French-AmericanBritish (FAB) Co-operative Group. Br J of Haematol 1976;33:451-458.

3 Druker BJ, Talpaz M, Resta DJ, et al: Efficacy and safety of a specific inhibitor of the BCR-ABL tyrosine kinase in chronic myeloid leukemia. New Engl J Med 2001;344:1031-1037.

4 Bennett JM, Catovsky D, Daniel MT, et al: Proposals for the classification of the myelodysplastic syndromes. Br J Haematol 1982;51:189-189.

5 Greenberg P, Cox C, LeBeau MM, et al: International scoring system for evaluating prognosis in myelodysplastic syndromes. Blood 1997;89:2079-2088.

6 Druker BJ, Tamura S, Buchdunger E, et al: Effects of a selective inhibitor of the Ab1 tyrosine kinase on the growth of Bcr-Ab1 positive cells. Nat Med 1996;2:561-566.

7 Rowley JD: A new consistent chromosomal abnormality in chronic myelogenous leukaemia identified by quinacrine fluorescence and Giemsa staining. Nature 1973;243:290-293.

8 Lapidot T, Sirard C, Vormoor J, et al: A cell initiating human acute myeloid leukaemia after transplantation into SCID mice. Nature 1994;367:645-648.

9 O'Brien SG, Guilhot F, Larson RA, et al: Imatinib compared with interferon and low-dose cytarabine for newly diagnosed chronic-phase chronic myeloid leukemia. New Engl J Med 2003;348:994-1004.

10 James C, Ugo V, Le Couédic JP, et al: A unique clonal JAK2 mutation leading to constitutive signalling causes polycythaemia vera. Nature 2005;434:1144-1148.

11 Druker BJ, Guilhot F, O'Brien SG, et al: Five-year follow-up of patients receiving imatinib for chronic myeloid leukemia. N Engl J Med 2006;355:2408-2417.

12 Kralovics R, Passamonti F, Buser AS, et al: A gain-of-function mutation of JAK2 in myeloproliferative disorders. N Engl J Med 2005;352:1779-1790.

13 Lozzio CB, Lozzio BB: Human chronic myelogenous leukemia cell-line with positive Philadelphia chromosome. Blood 1975;45:321-334.

14 Baxter EJ, Scott LM, Campbell PJ, et al: Acquired mutation of the tyrosine kinase JAK2 in human myeloproliferative disorders. Lancet 2005;365:1054-1061.

15 Bennett JM, Catovsky D, Daniel MT, et al: Proposed revised criteria for the classification of acute myeloid leukemia: a report of the French-American-British Cooperative Group. Ann Intern Med 1985;103:620-625.

16 Druker BJ, Sawyers CL, Kantarjian H, et al: Activity of a specific inhibitor of the BCR-ABL tyrosine kinase in the blast crisis of chronic myeloid leukemia and acute lymphoblastic leukemia with the Philadelphia chromosome. N Engl J Med 2001;344:1038-1042.

17 Grimwade D, Walker H, Oliver F, et al: The importance of diagnostic cytogenetics on outcome in AML: analysis of 1,612 patients entered into the MRC AML 10 trial. Blood 1998;92:2322-2333.

18 Levine RL, Wadleigh M, Cools J, et al: Activating mutation in the tyrosine kinase JAK2 in polycythemia vera, essential thrombocythemia, and myeloid metaplasia with myelofibrosis. Cancer Cell 2005;7:387-397.

19 Slavin S, Nagler A, Naparstek E, et al: Nonmyeloablative stem cell transplantation and cell therapy as an alternative to conventional bone marrow transplantation with lethal cytoreduction for the treatment of malignant and nonmalignant hematologic diseases. Blood 1998;91:756-763.

20 Bodey GP, Buckley M, Sathe Y, et al: Quantitative relationships between circulating leukocytes and infection in patients with acute leukemia. Ann Intern Med 1966;64:328-340.

21 Breitman TR, Selonick SE, Collins SJ: Induction of differentiation of the human promyelocytic leukemia cell line (HL60) by retinoic acid. Proc Natl Acad Sci 1980;77:2936-2940

22 Daley GQ, Van Etten RA, Baltimore D: Induction of chronic myelogenous leukemia in mice by the P210bcr/abl gene of the Philadelphia chromosome. Science 1990;247:824-830.

23 Kolb HJ, Schattenberg A, Goldman JM, et al: Graft-versus-leukemia effect of donor lymphocyte transfusions in marrow grafted patients. Blood 1995;86:2041-2050.

24 Kantarjian H, Sawyers C, Hochhaus A, et al: Hematologic and cytogenetic responses to imatinib mesylate in chronic myelogenous leukemia. N Engl J Med 2002;346:645-652.

25 Cheson BD, Bennett JM, Kopecky KJ, et al: Treatment outcomes, and reporting standards for therapeutic trials in acute myeloid leukemia: revised recommendations of the International Working Group for Diagnosis, Standardization of Response Criteria, Treatment Outcomes, and Reporting Standards for Therapeutic Trials in Acute Myeloid Leukemia. J Clin Oncol 2003;21:4642-4649.

26 Collins SJ, Ruscetti FW, Gallagher RE, et al: Terminal differentiation of human promyelocytic leukemia cells induced by dimethyl sulfoxide and other polar compounds. Proc Natl Acad Sci USA 1978;75:2458-2462.

27 Shah NP, Tran C, Lee FY, et al: Overriding imatinib resistance with a novel ABL kinase inhibitor. Science 2004:305:399-401.
4,039

3,984

3,760 
Table 1 (continued)

\begin{tabular}{|c|c|c|c|}
\hline Rank & Article & $\begin{array}{l}\text { Total } \\
\text { citations, } \\
n\end{array}$ & $\begin{array}{l}\text { Average } \\
\text { citations } \\
\text { per year, } n\end{array}$ \\
\hline 29 & $\begin{array}{l}\text { Cools J, DeAngelo DJ, Gotlib J, et al: A tyrosine kinase created by fusion of the PDGFRA and FIP1L1 genes as a thera- } \\
\text { peutic target of imatinib in idiopathic hypereosinophilic syndrome. N Engl J Med 2003;348:1201-1214. }\end{array}$ & 1,260 & 90 \\
\hline 31 & $\begin{array}{l}\text { Shah NP, Nicoll JM, Nagar B, et al: Multiple BCR-ABL kinase domain mutations confer polyclonal resistance to the } \\
\text { tyrosine kinase inhibitor imatinib (STI571) in chronic phase and blast crisis chronic myeloid leukemia. Cancer Cell } \\
2002 ; 2: 117-125 \text {. }\end{array}$ & 1,234 & 82.3 \\
\hline 32 & $\begin{array}{l}\text { Silverman LR, Demakos EP, Peterson BL, et al: Randomized controlled trial of azacitidine in patients with the myelo- } \\
\text { dysplastic syndrome: a study of the cancer and leukemia group B. J Clin Oncol 2002;20:2429-2440. }\end{array}$ & 1,197 & 79.8 \\
\hline 35 & $\begin{array}{l}\text { Talpaz M, Shah NP, Kantarjian H, et al: Dasatinib in imatinib-resistant Philadelphia chromosome-positive leukemias. } \\
\text { N Engl J Med 2006;354:2531-2541. }\end{array}$ & 1,168 & 106.2 \\
\hline 36 & $\begin{array}{l}\text { Kolb HJ, Mittermuller J, Clemm CH, et al: Donor leukocyte transfusions for treatment of recurrent chronic myelog- } \\
\text { enous leukemia in marrow transplant patients. Blood 1990;76:2462-2465. }\end{array}$ & 1,135 & 42.0 \\
\hline 37 & $\begin{array}{l}\text { McSweeney PA, Niederwieser D, Shizuru JA, et al: Hematopoietic cell transplantation in older patients with hematolog- } \\
\text { ic malignancies: replacing high-dose cytotoxic therapy with graft-versus-tumor effects. Blood 2001;97:3390-3400. }\end{array}$ & 1,109 & 69.3 \\
\hline 38 & $\begin{array}{l}\text { Figueroa ME, Abdel-Wahab O, Lu C, et al: Leukemic IDH1 and IDH2 mutations result in a hypermethylation pheno- } \\
\text { type, disrupt TET2 function, and impair hematopoietic differentiation. Cancer Cell 2010;18:553-567. }\end{array}$ & 1,095 & 156.4 \\
\hline 39 & $\begin{array}{l}\text { Kakizuka A, Miller WH, Umesono K, et al: Chromosomal translocation t }(15 ; 17) \text { in human acute promyelocytic leuke- } \\
\text { mia fuses RARa with a novel putative transcription factor, PML. Cell 1991;66:663-674. }\end{array}$ & 1,091 & 42.0 \\
\hline 40 & $\begin{array}{l}\text { Byrd JC, Mrózek K, Dodge RK, et al: Pretreatment cytogenetic abnormalities are predictive of induction success, cumu- } \\
\text { lative incidence of relapse, and overall survival in adult patients with de novo acute myeloid leukemia: results from } \\
\text { Cancer and Leukemia Group B (CALGB 8461). Blood 2002;100:4325-4336. }\end{array}$ & 1,077 & 71.8 \\
\hline 45 & $\begin{array}{l}\text { Mayer RJ, Davis RB, Schiffer CA, et al: Intensive postremission chemotherapy in adults with acute myeloid leukemia. N } \\
\text { Engl J Med 1994;331:896-903. }\end{array}$ & 1,044 & 45.4 \\
\hline 46 & $\begin{array}{l}\text { Weisberg E, Manley PW, Breitenstein W, et al: Characterization of AMN107, a selective inhibitor of native and mutant } \\
\text { Bcr-Abl. Cancer Cell 2005;7:129-141. }\end{array}$ & 1,035 & 86.3 \\
\hline 47 & $\begin{array}{l}\text { Warrell RP Jr, Frankel SR, Miller WH Jr, et al: Differentiation therapy of acute promyelocytic leukemia with tretinoin } \\
\text { (all-trans-retinoic acid). N Engl J Med 1991;324:1385-1393. }\end{array}$ & 1,016 & 39.1 \\
\hline 48 & $\begin{array}{l}\text { Ludwig WD, Matutes E, Orfao A, et al: Proposals for the immunological classification of acute leukemia. Leukemia } \\
\text { 1995;9:1783-1786. }\end{array}$ & 997 & 45.3 \\
\hline 49 & $\begin{array}{l}\text { Golub TR, Barker GF, Lovett M, et al: Fusion of PDGF receptor } \beta \text { to a novel ets-like gene, tel, in chronic myelomono- } \\
\text { cytic leukemia with t }(5 ; 12) \text { chromosomal translocation. Cell 1994;77:307-316. }\end{array}$ & 996 & 43.3 \\
\hline 50 & $\begin{array}{l}\text { Sawyers CL, Hochhaus A, Feldman E, et al: Imatinib induces hematologic and cytogenetic responses in patients with } \\
\text { chronic myelogenous leukemia in myeloid blast crisis: results of a phase II study. Blood 2002;99:3530-3539. }\end{array}$ & 973 & 64.9 \\
\hline 51 & $\begin{array}{l}\text { Schlenk RF, Döhner K, Krauter J, et al: Mutations and treatment outcome in cytogenetically normal acute myeloid } \\
\text { leukemia. N Engl J Med 2008;358:1909-1918. }\end{array}$ & 972 & 108 \\
\hline 52 & Ley TJ, Ding L, Walter MJ, et al: DNMT3A mutations in acute myeloid leukemia. N Engl J Med 2010;363:2424-2433. & 959 & 137 \\
\hline 53 & Delhommeau F, Dupont S, Valle VD, et al: Mutation in TET2 in myeloid cancers. N Engl J Med 2009;360:2289-2301. & 956 & 119.5 \\
\hline 54 & $\begin{array}{l}\text { Hughes TP, Kaeda J, Branford S, et al: Frequency of major molecular responses to imatinib or interferon alfa plus cyta- } \\
\text { rabine in newly diagnosed chronic myeloid leukemia. N Engl J Med 2003;349:1423-1432. }\end{array}$ & 939 & 67.1 \\
\hline
\end{tabular}


Table 1 (continued)

\begin{tabular}{|c|c|c|c|}
\hline Rank & Article & $\begin{array}{l}\text { Total } \\
\text { citations, } \\
n\end{array}$ & $\begin{array}{l}\text { Average } \\
\text { citations } \\
\text { per year, } n\end{array}$ \\
\hline 56 & $\begin{array}{l}\text { Kottaridis PD, Gale RE, Frew ME, et al: The presence of a FLT3 internal tandem duplication in patients with acute } \\
\text { myeloid leukemia (AML) adds important prognostic information to cytogenetic risk group and response to the first } \\
\text { cycle of chemotherapy: analysis of } 854 \text { patients from the United Kingdom Medical Research Council AML } 10 \text { and } 12 \\
\text { trials. Blood 2001;98:1752-1759. }\end{array}$ & 936 & 58.5 \\
\hline 57 & $\begin{array}{l}\text { Saglio G, Kim DW, Issaragrisil S, et al: Nilotinib versus imatinib for newly diagnosed chronic myeloid leukemia. N Engl } \\
\text { J Med 2010;362:2251-2259. }\end{array}$ & 935 & 133.6 \\
\hline 58 & $\begin{array}{l}\text { Klein A, van Kessel AG, Grosveld G, Bartram CR, Hagemeijer A, Bootsma D, Spurr NK, Heisterkamp N, Groffen J, } \\
\text { Stephenson JR: A cellular oncogene is translocated to the Philadelphia chromosome in chronic myelocytic leukaemia. } \\
\text { Nature 1982;300:765-767. }\end{array}$ & 912 & 26.1 \\
\hline 59 & $\begin{array}{l}\text { Kantarjian H, Issa JP, Rosenfeld CS, et al: Decitabine improves patient outcomes in myelodysplastic syndromes. Cancer } \\
\text { 2006;106:1794-1803. }\end{array}$ & 908 & 82.5 \\
\hline 62 & $\begin{array}{l}\text { Ding L, Ley TJ, Larson DE, et al: Clonal evolution in relapsed acute myeloid leukaemia revealed by whole-genome } \\
\text { sequencing. Nature 2012;481:506-510. }\end{array}$ & 851 & 170.2 \\
\hline 63 & $\begin{array}{l}\text { Valk PJ, Verhaak RG, Beijen MA, et al: Prognostically useful gene-expression profiles in acute myeloid leukemia. N } \\
\text { Engl J Med 2004;350:1617-1628. }\end{array}$ & 843 & 64.8 \\
\hline 64 & $\begin{array}{l}\text { Ward PS, Patel J, Wise DR, et al: The common feature of leukemia-associated IDH1 and IDH2 mutations is a neomor- } \\
\text { phic enzyme activity converting } \alpha \text {-ketoglutarate to 2-hydroxyglutarate. Cancer Cell 2010;17:225-234. }\end{array}$ & 832 & 118.9 \\
\hline 65 & $\begin{array}{l}\text { Graham SM, Jørgensen HG, Allan E, et al: Primitive, quiescent, Philadelphia-positive stem cells from patients with } \\
\text { chronic myeloid leukemia are insensitive to STI571 in vitro. Blood 2002;99:319-325. }\end{array}$ & 812 & 54.1 \\
\hline 66 & $\begin{array}{l}\text { Osserman EF, Lawlor DP: Serum and urinary lysozyme (muramidase) in monocytic and monomyelocytic leukemia. J } \\
\text { Exp Med 1966;124:921-952. }\end{array}$ & 811 & 15.9 \\
\hline 67 & $\begin{array}{l}\text { List A, Dewald G, Bennett J, et al: Lenalidomide in the myelodysplastic syndrome with chromosome 5q deletion. N } \\
\text { Engl J Med 2006;355:1456-1465. }\end{array}$ & 807 & 73.4 \\
\hline 72 & $\begin{array}{l}\text { Yoshida K, Sanada M, Shiraishi Y, et al: Frequent pathway mutations of splicing machinery in myelodysplasia. Nature } \\
\text { 2011;478:64-69. }\end{array}$ & 768 & 128 \\
\hline 73 & $\begin{array}{l}\text { Greenberg PL, Tuechler H, Schanz J, et al: Revised international prognostic scoring system for myelodysplastic syn- } \\
\text { dromes. Blood 2012;120:2454-2465. }\end{array}$ & 767 & 153.4 \\
\hline 74 & $\begin{array}{l}\text { Grimwade D, Hills RK, Moorman AV, et al: Refinement of cytogenetic classification in acute myeloid leukemia: deter- } \\
\text { mination of prognostic significance of rare recurring chromosomal abnormalities amongst 5,876 younger adult patients } \\
\text { treated in the UK Medical Research Council trials. Blood 2010;116:354-365. }\end{array}$ & 764 & 109.1 \\
\hline 75 & $\begin{array}{l}\text { Yamamoto Y, Kiyoi H, Nakano Y, et al: Activating mutation of D835 within the activation loop of FLT3 in human } \\
\text { hematologic malignancies. Blood 2001;97:2434-2439. }\end{array}$ & 763 & 47.7 \\
\hline 76 & $\begin{array}{l}\text { Scott LM, Tong W, Levine RL, et al: JAK2 exon } 12 \text { mutations in polycythemia vera and idiopathic erythrocytosis. N } \\
\text { Engl J Med 2007;356:459-468. }\end{array}$ & 741 & 74.1 \\
\hline 77 & $\begin{array}{l}\text { O'Hare T, Walters DK, Stoffregen EP, et al: In vitro activity of Bcr-Abl inhibitors AMN107 and BMS-354825 against } \\
\text { clinically relevant imatinib-resistant Abl kinase domain mutants. Cancer Res 2005;65:4500-4505. }\end{array}$ & 739 & 61.6 \\
\hline 78 & $\begin{array}{l}\text { Lanotte M, Martin-Thouvenin V, Najman S, et al: NB4, a maturation inducible cell line with t }(15 ; 17) \text { marker isolated } \\
\text { from a human acute promyelocytic leukemia (M3). Blood 1991;77:1080-1086. }\end{array}$ & 732 & 28.2 \\
\hline 79 & $\begin{array}{l}\text { Jin L, Hope KJ, Zhai Q, et al: Targeting of CD44 eradicates human acute myeloid leukemic stem cells. Nature Medicine } \\
\text { 2006;12:1167-1174. }\end{array}$ & 719 & 65.4 \\
\hline 80 & $\begin{array}{l}\text { Hochhaus A, Kreil S, Corbin AS, et al: Molecular and chromosomal mechanisms of resistance to imatinib (STI571) } \\
\text { therapy. Leukemia 2002;16:2190. }\end{array}$ & 709 & 47.3 \\
\hline
\end{tabular}


Table 1 (continued)

\begin{tabular}{|c|c|c|c|}
\hline Rank & Article & $\begin{array}{l}\text { Total } \\
\text { citations, } \\
n\end{array}$ & $\begin{array}{l}\text { Average } \\
\text { citations } \\
\text { per year, } n\end{array}$ \\
\hline 82 & $\begin{array}{l}\text { Pikman Y, Lee BH, Mercher T, et al: MPLW515L is a novel somatic activating mutation in myelofibrosis with myeloid } \\
\text { metaplasia. PLoS Med 2006;3:e270. }\end{array}$ & 705 & 64.1 \\
\hline 84 & $\begin{array}{l}\text { Leith CP, Kopecky KJ, Godwin J, et al: Acute myeloid leukemia in the elderly: assessment of multidrug resistance } \\
\text { (MDR1) and cytogenetics distinguishes biologic subgroups with remarkably distinct responses to standard chemother- } \\
\text { apy. A Southwest Oncology Group study. Blood 1997;89:3323-3329. }\end{array}$ & 702 & 35.1 \\
\hline 85 & $\begin{array}{l}\text { Miyoshi H, Shimizu K, Kozu T, et al: } \mathrm{t}(8 ; 21) \text { breakpoints on chromosome } 21 \text { in acute myeloid leukemia are clustered } \\
\text { within a limited region of a single gene, AML1. Proc Natl Acad Sci USA 1991;88:10431-10434. }\end{array}$ & 698 & 26.8 \\
\hline 86 & $\begin{array}{l}\text { Bullinger L, Döhner K, Bair E, et al: Use of gene-expression profiling to identify prognostic subclasses in adult acute } \\
\text { myeloid leukemia. N Engl J Med 2004;350:1605-1616. }\end{array}$ & 697 & 53.6 \\
\hline 88 & $\begin{array}{l}\text { Valent P, Horny HP, Escribano L, et al: Diagnostic criteria and classification of mastocytosis: a consensus proposal. } \\
\text { Leuk Res 2001;25:603-625. }\end{array}$ & 691 & 43.2 \\
\hline 89 & $\begin{array}{l}\text { Goldman JM, Gale RP, Horowitz MM, et al: Bone marrow transplantation for chronic myelogenous leukemia in chron- } \\
\text { ic phase: increased risk for relapse associated with T-cell depletion. Ann Intern Med 1988;108:806-814. }\end{array}$ & 684 & 23.6 \\
\hline 90 & $\begin{array}{l}\text { Bejar R, Stevenson K, Abdel-Wahab O, et al: Clinical effect of point mutations in myelodysplastic syndromes. N Engl J } \\
\text { Med 2011;364:2496-2506. }\end{array}$ & 677 & 112.8 \\
\hline 91 & $\begin{array}{l}\text { Malcovati L, Germing U, Kuendgen A, et al: Time-dependent prognostic scoring system for predicting survival and leu- } \\
\text { kemic evolution in myelodysplastic syndromes. J Clin Oncol 2007;25:3503-3510. }\end{array}$ & 669 & 66.9 \\
\hline 92 & $\begin{array}{l}\text { O'Farrell AM, Abrams TJ, Yuen HA, et al: SU11248 is a novel FLT3 tyrosine kinase inhibitor with potent activity in } \\
\text { vitro and in vivo. Blood 2003;101:3597-3605. }\end{array}$ & 668 & 47.7 \\
\hline 93 & $\begin{array}{l}\text { Grimwade D, Walker H, Harrison G, et al: The predictive value of hierarchical cytogenetic classification in older adults } \\
\text { with acute myeloid leukemia (AML): analysis of 1,065 patients entered into the United Kingdom Medical Research } \\
\text { Council AML11 trial. Blood 2001;98:1312-1320. }\end{array}$ & 666 & 41.6 \\
\hline 98 & $\begin{array}{l}\text { Mackinnon S, Papadopoulos EB, Carabasi MH, et al: Adoptive immunotherapy evaluating escalating doses of donor } \\
\text { leukocytes for relapse of chronic myeloid leukemia after bone marrow transplantation: separation of graft-versus-leuke- } \\
\text { mia responses from graft-versus-host disease. Blood 1995;86:1261-1268. }\end{array}$ & 642 & 29.2 \\
\hline 99 & $\begin{array}{l}\text { Ernst T, Chase AJ, Score J, et al: Inactivating mutations of the histone methyltransferase gene EZH2 in myeloid disor- } \\
\text { ders. Nat Genet 2010;42:722-776. }\end{array}$ & 641 & 91.6 \\
\hline 100 & List A, Kurtin S, Roe DJ, et al: Efficacy of lenalidomide in myelodysplastic syndromes. N Engl J Med 2005;352:549-557. & 636 & 53 \\
\hline
\end{tabular}

of 156 authors contributed to the 100 articles on our list, with all of them having coauthored at least 2 articles. The number of authors per paper ranged from 1 to 141, with a median number of 13 authors per article. The greatest number of articles were coauthored by $\mathrm{H}$. Kantarjian $(n=12)$, along with other major contributors, i.e., A. Hochhaus $(n=11)$ and J.M. Bennet $(n=10)$. Table 2 lists the top authors in the field of myeloid neoplasms, along with their $\mathrm{H}$ indices and institutional affiliations. As depicted in Table 3, the Dana-Farber Cancer Institute $(n=$ 18 ) and the University of Texas MD Anderson Cancer Center $(n=18)$ were affiliated with the greatest number of articles on the list, followed by Harvard Medical School $(n=11)$, Novartis International AG $(n=11)$, and the University of Chicago $(n=11)$. 
Fig. 1. Total citations of the articles in the top 100 list every year. The line depicts the initial steady number and then great rise in the number of total citations over the years.

Fig. 2. Number of publications in each 5 -year interval period.
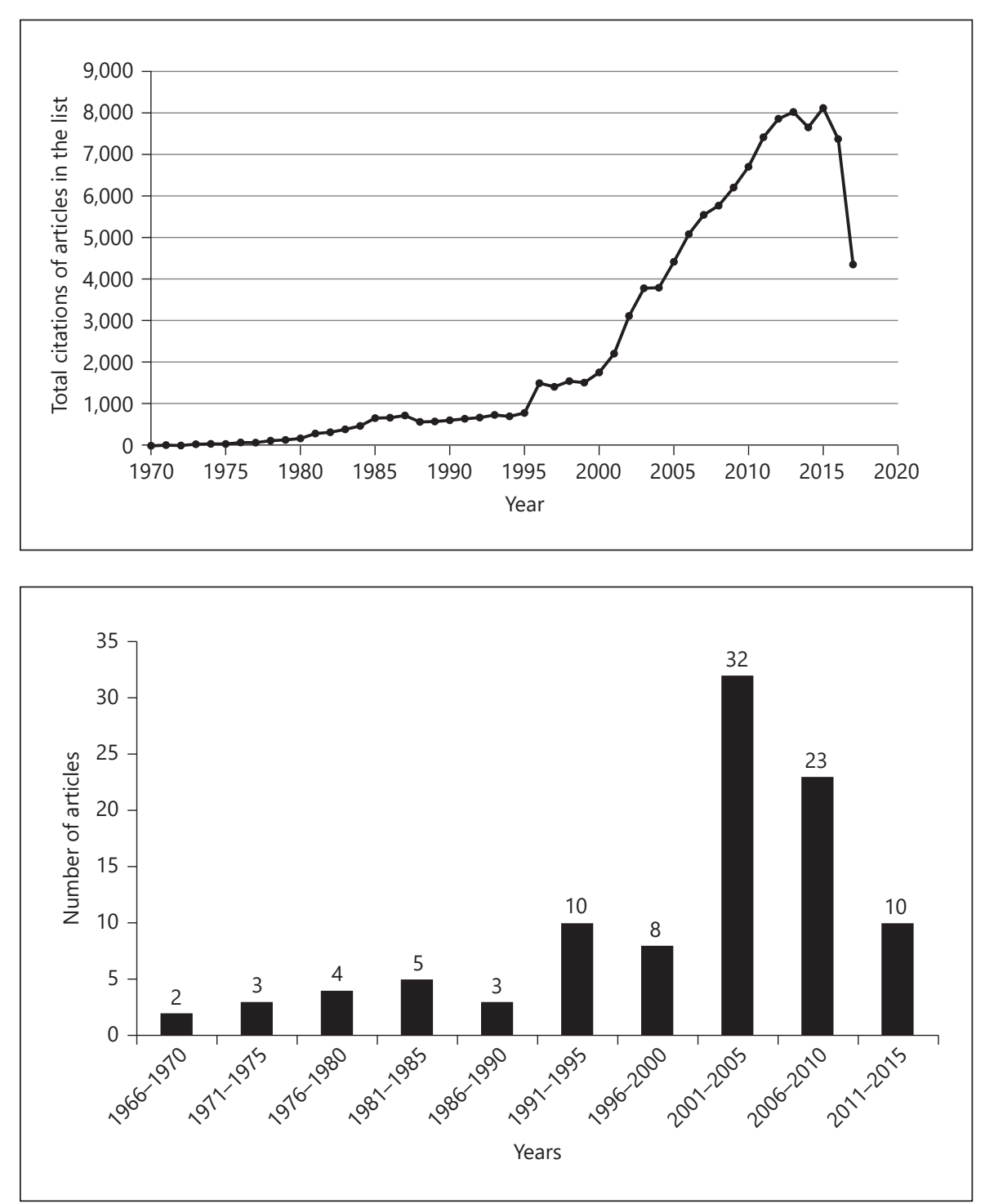

The New England Journal of Medicine was the journal with the highest number of articles published, followed by Blood and Nature. The impact factor of the journals ranged from 2.13 to 72.40 . We found a significant correlation between the impact factor of the journal and the number of articles published in that journal. Furthermore, Table 4 categorizes the articles published in each journal according to their main focus. The greatest number of articles concerning CML were published in the New England Journal of Medicine $(n=10)$, while those concerning AML were published equally in the New England Journal of Medicine $(n=8)$ and Blood $(n=8)$.

\section{Discussion}

The 100 most frequently cited articles relevant to myeloid neoplasms identified by our bibliometric analysis are listed in Table 1. These 100 articles represent the fundamental core of research in this area and have helped shape the understanding of these disorders. Through this analysis, we obtained the overall citation activity and distribution for these 100 cited articles, which can aid in providing better discernment about the concentration, distribution, and development of research trends in this particular area of interest.

Figure 2 highlights that the articles on our 100 mostcited list were published over a span of many years, i.e., from 1966 to 2015 . However, the greatest number of ar- 


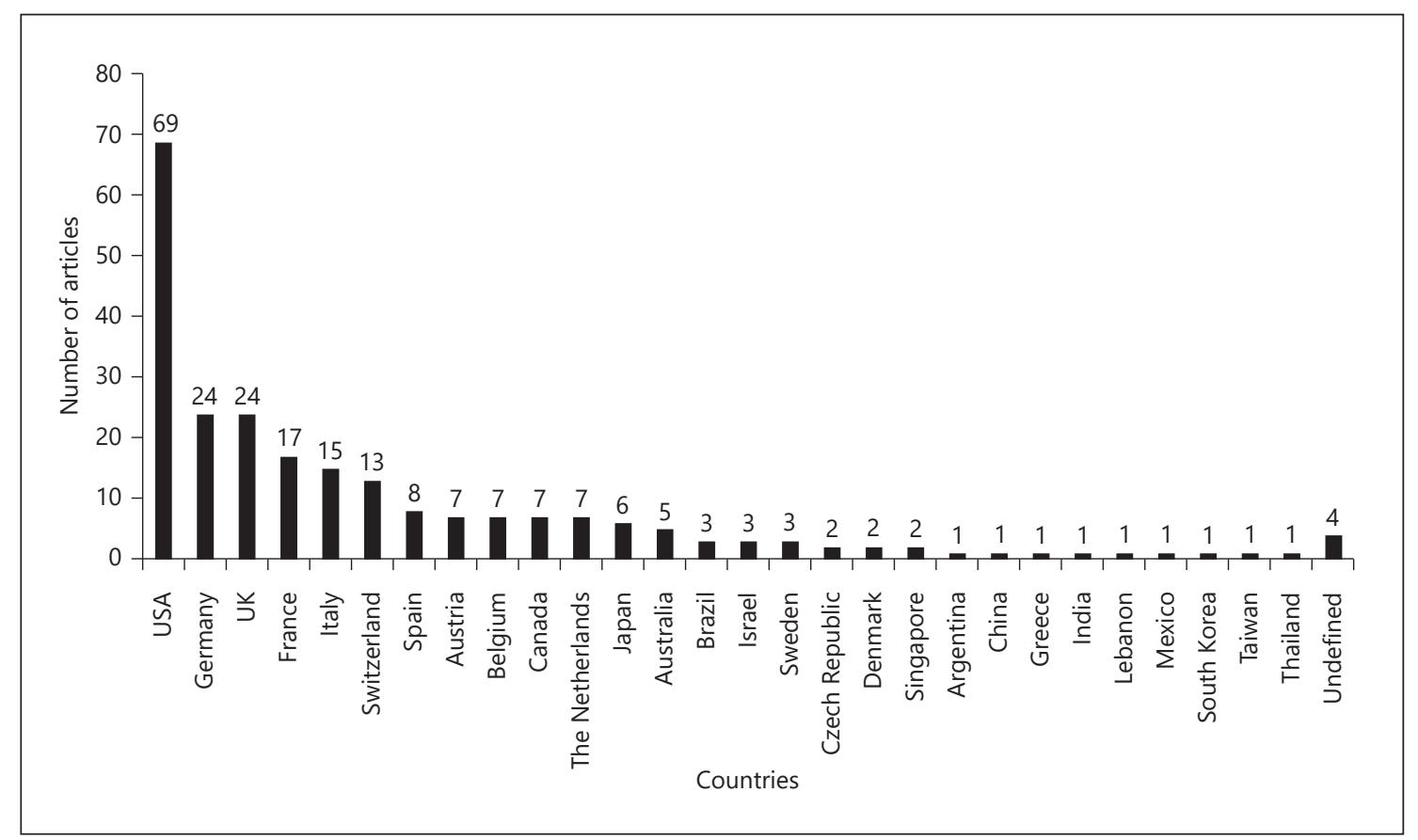

Fig. 3. Number of articles originating from each country.

ticles $(n=65)$ were published between 2001 and 2015, reflecting the dramatic upsurge of research activity in myeloid leukemias that accompanied the introduction of genomic and proteomic approaches to analysis as well as the development of novel targeted therapies. This is in contrast with bibliometric studies of other well-established fields of medicine like general surgery [10], orthopedics [11], and neurosurgery [12] that published most of their citation classics before the 1980s. However, some other fields show a similar pattern of publications like cardiovascular magnetic resonance [12] and diabetes mellitus [13]. The obliteration-by-incorporation phenomenon [17] may also be in play, suggesting that some landmark articles may not be cited as frequently anymore because the information that they have provided has become so widely incorporated into the medical field that researchers do not feel the need to cite such studies. Hence, this phenomenon often contributes to the recent peak time periods in bibliometric studies. A slight decline was observed in the publication number from 2011 to 2015. This may be explained by the fact that some elapsed time is needed for the publications to gather citations and significant reportage. Moreover, inherent bias of bibliometrics towards recent papers may lead to exclusion of some important research papers [18]. Another bibliometric analysis in the future will be able to better scrutinize this particular trend in research pertaining to myeloid neoplasms. There are no articles published before 1966, highlighting that old articles have limited significance as research advances to new peaks in this recent era.

The citation count is known to be an effective indicator of the overall impact of an article; however, it fails to highlight the article's current influence. In order to know how important an article is at the moment, we included the "citations per year" in Table 1 as well. The article titled, "Human acute myeloid leukemia is organized as a hierarchy that originates from a primitive hematopoietic cell" had the greatest number of citations and citations per year.

Table 4 showcases the journals that published the majority of the top 100 cited articles. These journals may be deemed as forming a part of the "zone 1" journals as stated by Bradford's law [19]. This law affirms that zone 1 journals in any given field are those that are the most heavily read and cited within that field. If authors deviate from these core journals, the impact of their article in their area of focus may be reduced. More than half of the top 100 cited articles $(n=53)$ were published in 2 major journals, i.e., the New England Journal of Medicine and Blood. The New England Journal of Medicine is a very high 
Table 2. Authors with 5 or more articles on the top 100 list

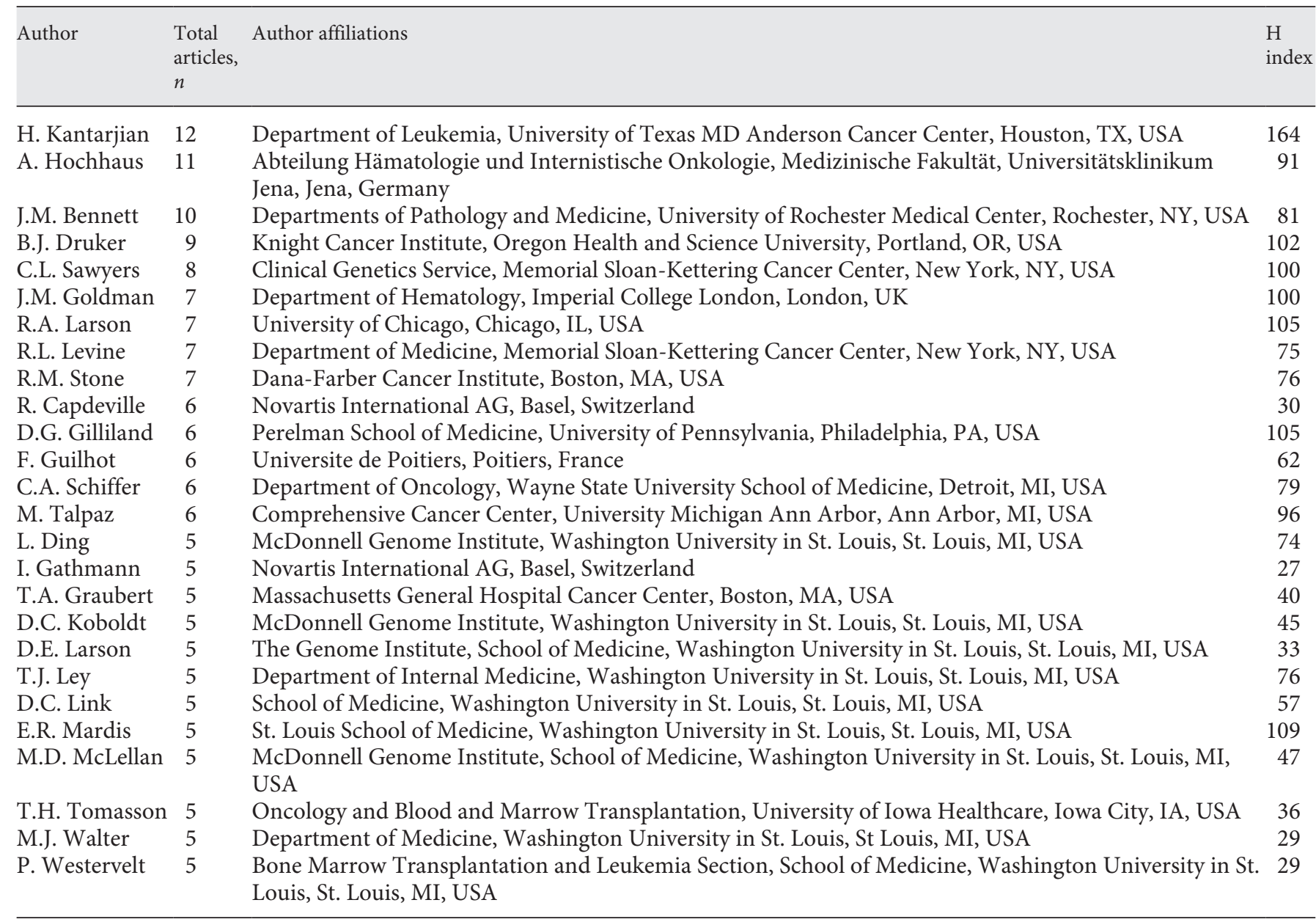

Table 3. Institution affiliated with more than 7 articles on the list

\begin{tabular}{ll}
\hline Institute & $\begin{array}{l}\text { Documents, } \\
n\end{array}$ \\
\hline Dana-Farber Cancer Institute & 18 \\
University of Texas MD Anderson Cancer Center & 18 \\
Harvard Medical School & 11 \\
Novartis International AG & 11 \\
University of Chicago & 11 \\
Hôpital Saint-Louis & 10 \\
Howard Hughes Medical Institute & 10 \\
Oregon Health and Science University & 9 \\
Universität Heidelberg & 9 \\
University of California, Los Angeles & 9 \\
Universitätsklinikum Mannheim & 8 \\
Memorial Sloan-Kettering Cancer Center & 8 \\
Brigham and Women's Hospital & 8 \\
\hline
\end{tabular}

impact journal that caters to a wide array of audiences, whereas Blood, despite its high profile, is a specialty-specific journal relevant to the field of hematology. This shows that research being done on myeloid neoplasms aims to encompass and reach out to a broad audience, both within this particular field of medicine and generally. As depicted by other studies as well [14-16], we saw that there is an increasing trend towards publishing highimpact articles in specialty journals compared to other high-impact journals. In addition, there is a lack of significant correlation between the number of 100 most cited articles and the impact factor of a journal, reinforcing that high-quality, influential research will earn citations independently of the journal that it is published in.

Our analysis revealed that the greatest number of articles on the list $(n=69)$ originated from the USA, probably owing to the funding support provided by the NIH and other private sectors, promoting research. This lines up with find- 
Table 4. Journals with more than 2 articles on the list

\begin{tabular}{llllll}
\hline Journal & $\begin{array}{l}\text { Articles, } \\
n\end{array}$ & $\begin{array}{l}\text { Articles } \\
\text { concerning } \\
\text { AML, } n\end{array}$ & $\begin{array}{l}\text { Articles } \\
\text { concerning } \\
\text { CML, } n\end{array}$ & $\begin{array}{l}\text { Others, } \\
n\end{array}$ & $\begin{array}{l}2016 \\
\text { impact } \\
\text { factor }\end{array}$ \\
\hline New England Journal of Medicine & 30 & 8 & 10 & 12 & 72.406 \\
Blood & 23 & 8 & 5 & 10 & 13.164 \\
Nature & 10 & 4 & 3 & 3 & 40.137 \\
Cancer Cell & 5 & 0 & 1 & 4 & 27.407 \\
Annals of Internal Medicine & 3 & 2 & 1 & 0 & 17.202 \\
Cell & 3 & 0 & 0 & 3 & 30.410 \\
Journal of Clinical Oncology & 3 & 1 & 0 & 2 & 24.008 \\
Leukemia & 3 & 2 & 0 & 1 & 11.702 \\
Nature Medicine & 3 & 2 & 0 & 29.886 \\
Proceedings of National Academy of Science & 3 & 1 & & 9.661 \\
\hline
\end{tabular}

ings of previous studies $[10,11]$. Several European countries like Germany, the UK, and France followed, but the contribution from Asian countries was minimal.

Authors, worldwide, expect and need their individual work to be recognized and supported. This helps boost their academic and scientific work and acts to propel career advancement. Prominent authors who have their work acknowledged by the scientific community are often promoted early and held in high esteem. Research bodies are more likely to accept their work and may also ask them to act as reviewers [20]. Our study indicated that 26 authors had 5 or more publications on the 100-most-cited list, and hence, were the main forerunners in myeloid neoplasms research. In comparison, a bibliometric analysis done in the field of thrombolytic therapy identified 17 authors who had 5 or more articles on the top 100 list [21]. However, citation classics from other well-established fields have shown fewer numbers of influential authors $[22,23]$, suggesting that compared to these fields there is greater diversity of thought leaders in myeloid leukemia research.

Like other bibliometric analyses published, there are potential limitations to our study as well. Firstly, it has been reported that Scopus tends to miss older citations, which can lead to deletion of articles published in the pre1980 s era from our assembled list $[24,25]$. Secondly, $8 \%$ of the total citations were actually author self-citations. This is higher than the average self-citation percentage (i.e., 6.5\%) in general medicine [26]. This is an indication that journal citations maybe skewed owing to author selfcitations or a large number of people questioning badly researched findings. This was expected, noting that many of our authors had collaborated on many studies. Thirdly, the citation frequency may showcase the impact of an ar- ticle but it does not tell us about the quality of a study. For this purpose, citation analysis combined with more qualitative methods would be suitable to get a more all-inclusive idea of the significance of an article [27]. Fourthly, some of the recently published, impactful articles, despite holding future significant implications, may not have made it to the top 100 most-cited list as it takes time to garner citations [19]. Lastly, only one database (i.e., Scopus) was used in this analysis, which could have resulted in the loss of those articles not recorded in Scopus. Furthermore, citation counts and $\mathrm{H}$ indices may also vary from those derived from other competing databases. Despite these limitations, our study provides valuable insight into the most frequently read and cited articles relating to myeloid neoplasms.

\section{Conclusion}

In summary, this bibliometric analysis identified the 100 top-cited articles pertaining to myeloid neoplasms and characterized the trends in research. These articles have been carefully selected from medical literature through objective metrics and will service both researchers and clinicians. An appraisal of the top-cited articles identifies the place toward which the field is steering, the emerging avenues in research, and which areas still need more research attention so that the funding agencies can direct their resources accordingly.

\section{Disclosure Statement}

The authors declare no conflict of interests. 


\section{References}

1 Luukkonen T. Bibliometrics and evaluation of research performance. Ann Med. 1990 Jun; 22(3): $145-50$

2 Cooper ID. Bibliometrics basics. J Med Libr Assoc. 2015 Oct;103(4):217-8.

3 Wallin JA. Bibliometric methods: pitfalls and possibilities. Basic Clin Pharmacol Toxicol. 2005 Nov;97(5):261-75.

4 Ellegaard O, Wallin JA. The bibliometric analysis of scholarly production: how great is the impact? Scientometrics. 2015;105(3): 1809-31.

5 Agarwal A, Durairajanayagam D, Tatagari S, Esteves SC, Harlev A, Henkel R, et al. Bibliometrics: tracking research impact by selecting the appropriate metrics. Asian J Androl. 2016 Mar-Apr;18(2):296-309.

6 Vardiman JW. The World Health Organization (WHO) classification of tumors of the hematopoietic and lymphoid tissues: an overview with emphasis on the myeloid neoplasms. Chem Biol Interact. 2010 Mar;184(12):16-20.

7 Lichtman MA. Battling the hematological malignancies: the 200 years' war. Oncologist. $2008 \mathrm{Feb} ; 13(2): 126-38$.

8 Arber DA, Orazi A, Hasserjian R, Thiele J, Borowitz MJ, Le Beau MM, Bloomfield CD, Cazzola M, Vardiman JW. The 2016 revision to the World Health Organization (WHO) classification of myeloid neoplasms and acute leukemia. Blood. 2016 May;127(20):2391405.

9 Lim KJ, Yoon DY, Yun EJ, Seo YL, Baek S, Gu $\mathrm{DH}$, et al. Characteristics and trends of radiology research: a survey of original articles published in AJR and Radiology between 2001 and 2010. Radiology. 2012 Sep;264(3):796802 .
10 Paladugu R, Schein M, Gardezi S, Wise L. One hundred citation classics in general surgical journals. World J Surg. 2002 Sep;26(9):1099105.

11 Lefaivre KA, Shadgan B, O’Brien PJ. 100 most cited articles in orthopaedic surgery. Clin Orthop Relat Res. 2011 May;469(5):1487-97.

12 Ponce FA, Lozano AM. Highly cited works in neurosurgery. Part I: the 100 top-cited papers in neurosurgical journals. J Neurosurg. 2010 Feb;112(2):223-32.

13 Shuaib W, Costa JL. Anatomy of success: 100 most cited articles in diabetes research. Ther Adv Endocrinol Metab. 2015 Aug;6(4):16373.

14 Hennessey K, Afshar K, Macneily AE. The top 100 cited articles in urology. Can Urol Assoc J. 2009 Aug;3(4):293-302.

15 Brandt JS, Downing AC, Howard DL, Kofinas JD, Chasen ST. Citation classics in obstetrics and gynecology: the 100 most frequently cited journal articles in the last 50 years. Am J Obstet Gynecol. 2010 Oct;203(4):355.e1-7.

16 Usman MS, Siddiqi TJ, Khan MS, Fatima K, Butler J, Manning WJ, et al. A scientific analysis of the 100 citation classics of valvular heart disease. Am J Cardiol. 2017 Oct;120(8): 1440-9.

17 Sztompka P. Society in action: The theory of social becoming. Chicago: University of Chicago Press; 1991.

18 Seglen PO. Citation rates and journal impact factors are not suitable for evaluation of research. Acta Orthop Scand. 1998 Jun;69(3): 224-9.
19 Brookes BC. Bradford's law and the bibliography of science. Nature. 1969 Dec;224(5223): 953-6.

20 Stossel TP. Volume: papers and academic promotion. Ann Intern Med. 1987 Jan;106(1): 146-9.

21 Siddiqi TJ, Usman MS, Khan MS, Fatima K, Norbash A, Qureshi AI, et al. The 100 most influential papers in the field of thrombolytic therapy: a bibliometric analysis. Am J Cardiovasc Drugs. 2017 Aug;17(4):319-33.

22 Shuaib W, Acevedo JN, Khan MS, Santiago LJ, Gaeta TJ. The top 100 cited articles published in emergency medicine journals. Am J Emerg Med. 2015 Aug;33(8):1066-71.

23 Dubin D, Häfner AW, Arndt KA. Citation classics in clinical dermatologic journals. Citation analysis, biomedical journals, and landmark articles, 1945-1990. Arch Dermatol. 1993 Sep;129(9):1121-9.

24 Falagas ME, Pitsouni EI, Malietzis GA, Pappas G. Comparison of PubMed, Scopus, web of science, and Google scholar: strengths and weaknesses. FASEB J. 2008 Feb;22(2):33842.

25 Bakkalbasi N, Bauer K, Glover J, Wang L. Three options for citation tracking: Google Scholar, Scopus and Web of Science. Biomed Digit Libr. 2006 Jun;3(1):7.

26 Kulkarni AV, Aziz B, Shams I, Busse JW. Author self-citation in the general medicine literature. PLoS One. 2011;6(6):e20885.

27 Moed HF. The impact-factors debate: the ISI's uses and limits. Nature. 2002 Feb; 415(6873):731-2. 